\title{
The effects of service offshoring on employment
}

\section{CARMEN MARTÍNEZ-MORA}

Departamento Análisis Económico Universidad de Alicante Aptdo. Correos, 99-03080 Alicante e-mail: cmmora@ua.es Telefono: 965903400 ext.2893

BEGOÑA FUSTER

Departamento Análisis Económico Universidad de Alicante Aptdo. Correos, 99-03080 Alicante e-mail: bfuster@ua.es Telefono: 965903400 ext.2712

\author{
ADELAIDA LILLO-BAÑULS \\ Departamento Análisis Económico \\ Universidad de Alicante \\ Aptdo. Correos, 99-03080 Alicante \\ e-mail: alillo@ua.es \\ Telefono: 965903400 ext.2709
}

\section{Introduction}

From the beginning of this century, there has been a marked increase in the internationalisation of the service sector in all advanced economies. The implementation of offshoring strategies constitutes one of the major practices involved in this process.

Hardly a decade ago, most services were non-tradable and therefore did not lend themselves to offshoring. However, the intense development of new information technologies has made it possible for a growing number of activities to be carried out in locations other than those of the companies that require them in order to provide their finished goods or services (Bradford and Kletzer, 2005; Blinder, 2006; Contractor et al., 2010; Metters, 2007; Stratman, 2008; Aksin and Masini, 2008; Stringlelow et al., 2008; Vivek et al., 2008). This, together with intense global competition and the competitive price pressures faced by companies has led them to place greater focus on achieving efficiency and cost reductions by fragmenting their production processes and relocating them in countries offering greater competitive advantages. These strategies have been followed by both manufacturing and service companies. 
However, offshoring has been the target of considerable criticism over the past two decades, especially in recent years as a result of the intensification of the global economic crisis. The main arguments brandished by some of its opponents are based on the shortterm job losses in developed countries deriving from the relocation of operations to other countries offering competitive advantages in production costs, essentially consisting in cheaper labour. Protectionism advocates have raised their voices, calling for steps to put a brake on the growing internationalisation of company operations in various forms, including manufacturing goods in foreign countries and importing material and services inputs. However, economic analysis shows that the international operations of companies, not only through the free trading of end products, but also of inputs, leads to improved welfare in the countries involved (Olsen, 2006; Blinder, 2006; Grossman and RossiHansberg, 2008).

When a domestic company relocates parts of its production processes to other countries, there may be a resulting short-term drop in labour demand associated with the offshored activities, in the case where these activities were formerly carried out in the home country. However, when companies adopt this strategy, they also reinforce and extend the operations that they continue to carry out in their own country (Myro and Labrador, 2008), which are those that can be performed more efficiently in house and which require higher levels of qualification, thus leading to a rise in productivity (Amiti and Wei, 2009; Gorg and Hanley, 2005a; Winkler, 2010; Fariñas et al., 2010). Moreover, locating the different stages of production processes in the most efficient places with the lowest costs enhances efficiency and competitiveness (Olsen, 2006), allowing companies to reduce their average costs and the end prices of their products (Crinò, 2009). All of this will lead to increased production in the long term, resulting in rises in labour demand. However, in the case of specialised processes of companies within the global value chain, the offshoring strategy does not necessarily imply the abandonment in the home country of the activities that are outsourced abroad. In this instance, could not generate negative effects on employment; only positive effects are derived from the efficiency gains associated to the strategy.

When activities in the home country are abandoned, leading to potentially detrimental short and long-term effects on employment, a relevant observation must be considered. This is that when domestic companies adopt competitive strategies involving offshoring, 
although they could generate a net negative impact on employment, the resulting cost reduction and productivity gains could determine their survival in the market and the viability of financing new projects, which might otherwise not be feasible in the absence of such a competitiveness strategy (Bhagwati et al., 2004).

In any event, given that the theoretical forecasts regarding the final impact of offshoring on employment levels can be ambiguous, sometimes with opposite signs in the short and the long term, empirical studies are required to determine the outcome in each case, as noted by other authors (Hijzen et al., 2011).

This study carries out an empirical analysis of the impact of relocating the operations of Spanish service companies abroad on employment in the service sector. In other words, the study analyses the offshoring of services in the service industry and its impact on employment levels in that sector. This approach is different from the one adopted by most previous studies, which analyse the impacts of the offshoring of services on employment levels in manufacturing industries. The empirical analysis has been performed by estimating a labour demand function with constant elasticity of substitution (CES), including the effect of offshoring. The period of the analysis is 2000-2007 and the data used has been drawn from the Input-Output Tables of the Spanish National Accounts published by the Spanish National Statistics Institute (INE).

The study is structured as follows: Section 2 reviews the results of previous empirical evidence and suggests possible reasons for the differences found between these studies. In Section 3 the service offshoring indices calculated for the Spanish economy over the 2000-2007 period are analysed. In Section 4 the labour demand function including the offshoring indices is presented, together with the main results of the empirical estimation. Lastly, the main conclusions are drawn in the final section.

\section{Previous empirical evidence}

There is broad empirical evidence of the impact of offshoring on employment. If we classify the research available according to the methodology used, we can distinguish between descriptive studies and those that carry out an econometric estimation. The latter can, in turn, be divided into sectoral studies based mainly on input-output data and those that use company level data. 
Most existing research refers to the manufacturing sector and analyses the impact of the offshoring of material inputs and, to a lesser extent, of service activities, on employment in the manufacturing industry. However, there are fewer studies analysing the impact of the offshoring of services on overall employment levels in the service industry as a whole.

In this study we have analysed the latter case in the context of the Spanish economy, for which studies exist on the offshoring of manufacturing and material inputs ${ }^{1}$,-but there are no previous studies focusing on services.

We shall now review the existing literature analysing the impact on employment of the offshoring of service activities using sectoral data, both for the service industry and for manufacturing ${ }^{2}$. We will also consider the studies based on company data and, lastly, descriptive studies.

The econometric studies use sectoral data drawing from the manufacturing industry in some cases and the service industry in others. In all cases a linear labour demand function is estimated from a homogeneous production function with constant returns to scale (CES) including, as a measure of the offshoring of services, in some cases the proportion of imported service inputs relative to the total inputs used, and in others relative to the total production value (Table 1).

In the studies by Amiti and Wei, (2005, 2009), Winkler (2010), and Wright (2014) inputoutput data are analysed only for the manufacturing industry in different countries and for different periods of time. The former two studies measure the impact of offshoring on employment in the service industry as a whole, while Wright (2014) distinguishes between the impact on skilled and unskilled labour. The results obtained in terms of total employment reveal some differences and have a negative sign in some cases and little significance in others.

Meanwhile, Michel and Rycx (2012), and Agnese (2012) use data from Supply and Use Tables (SUT) and Input-Output Tables (IOT) respectively both for manufacturing

\footnotetext{
${ }^{1}$ Cadarso et al. (2008, 2012).

${ }^{2}$ In Crinò (2009) we can find a review of the wider literature on the effects of offshoring on employment, both in manufacturing and in services, including both material inputs and service activities.
} 
industries and for services. They refer to a similar period of time, between the mid-1990s and the mid 2000s, for two different countries, Belgium and Japan. In the former study, two estimates are made with static and dynamic labour demand functions. In both cases, for the service industries the results show no significant impact on employment can be observed. The use of data referring to the imports in intermediary products in this study drawn directly from trade data enables the intensity of offshoring by country of origin to be classified and the imports of inputs from high-wage and low-wage countries to be distinguished. In this way, a negative result is obtained, although with a very small coefficient $(10 \%)$ for offshoring in low-wage countries. This is consistent with the type of services that are usually offshored in these countries, replacing the less skilled tasks of the home country. Agnese (2012) uses a panel data analysis to estimate a labour demand function that distinguishes between different levels of qualification of the labour force in order to analyse the impact of offshoring on each of the different types of employment. A positive impact of the offshoring of services on skilled work is obtained, which is explained by the complementarity effect of the relocated operations with those that are retained or expanded within domestic borders.

The results of the above research show some differences in terms of the sign and extent of the impact of offshoring on employment levels. As pointed out by Horgos (2009), apart from the data used in the analysis, this is due to the different offshoring indices used, as well as the level of disaggregation of the sectoral data. In general, a higher degree of disaggregation leads to negative effects, while the effects obtained take a positive sign when the analyses are based on more aggregated data. This is explained by the fact that when more aggregated data are used, the results capture the compensating effects of jobcreating industries on job-destructing industries. However, it should be noted that in both cases the effects are found to be small, possibly due to the fact that, despite the rising trend in the offshoring of services in all countries in recent years, its scope is still limited.

Another feature of the above-mentioned literature based on sectoral data is that it does not take into account whether the offshoring or relocation of the different types of jobs takes place within the companies or not, this being a relevant factor that affects the greater or lesser difficulty in making adjustments in the workforce and, therefore, the net impact on employment. These issues can be identified in the available studies based on company data, the most widely used in the recent literature. It should be noted, however, that in 
such cases the measured impacts on employment are always of a short-term nature and do not take into account the potential positive long-term compensating effects of the productivity gains achieved through the offshoring strategy.

Table 1. Effects of Offshoring of Services on Employment Using Sectoral Data

\begin{tabular}{|c|c|c|c|c|}
\hline Study & Country & Sample & Measure of Offshoring & Effect on Employment \\
\hline $\begin{array}{l}\text { Amiti and Wei } \\
\text { (2009) }\end{array}$ & U.S. & $\begin{array}{l}\text { Input-output data. } \\
450 \text { and } 96 \text { industries } \\
\text { (manufacturing) } \\
1992-2000\end{array}$ & $\begin{array}{l}\text { Ratio of imported service } \\
\text { inputs to total non-energy } \\
\text { inputs }\end{array}$ & $\begin{array}{l}\text { Negative for } 450 \text { industries } \\
\text { and non-significant for } 96 \\
\text { industries }\end{array}$ \\
\hline $\begin{array}{l}\text { Amiti and Wei } \\
(2005)\end{array}$ & UK & $\begin{array}{l}\text { Input-output data. } \\
69 \text { industries } \\
\text { (manufacturing) } \\
1995-2001\end{array}$ & $\begin{array}{l}\text { Ratio of imported service } \\
\text { inputs to total non-energy } \\
\text { inputs }\end{array}$ & Positive, non-significant \\
\hline Winkler (2010) & Germany & $\begin{array}{l}\text { Input-output data. } \\
35 \text { industries } \\
\text { (manufacturing) } \\
1995-2006 \\
1997-2007 \\
\end{array}$ & $\begin{array}{l}\text { Ratio of imported service } \\
\text { inputs to total non-energy } \\
\text { inputs }\end{array}$ & Negative, significant \\
\hline $\begin{array}{l}\text { Michel and Rycx } \\
\text { (2012) }\end{array}$ & Belgium & $\begin{array}{l}\text { Data on imported } \\
\text { intermediates from } \\
\text { use of table of } \\
\text { imports } \\
\text { Manufacturing and } \\
\text { market services } \\
120 \text { industries } \\
35 \text { service industries } \\
1995-2003\end{array}$ & $\begin{array}{l}\text { Ratio of imported service } \\
\text { inputs to total production } \\
\text { value }\end{array}$ & $\begin{array}{l}\text { Negative, low level of } \\
\text { significance }\end{array}$ \\
\hline Agnese (2012) & Japan & $\begin{array}{l}\text { Input-output data. } \\
\text { Manufacturing, } \\
\text { service and primary } \\
\text { sector } \\
108 \text { industries } \\
1995,2000 \& 2005\end{array}$ & $\begin{array}{l}\text { Ratio of imported service } \\
\text { inputs to total non-energy } \\
\text { inputs }\end{array}$ & $\begin{array}{l}\text { Positive for the highly } \\
\text { skilled job segment } \\
\text { (professional and technical) }\end{array}$ \\
\hline Wright (2014) & U.S. & $\begin{array}{l}\text { Input-output data. } \\
\text { Manufacturing } \\
\text { industry } \\
2001-2007\end{array}$ & $\begin{array}{l}\text { Ratio of imported inputs to } \\
\text { final production }\end{array}$ & $\begin{array}{l}\text { Negative for unskilled jobs } \\
\text { and positive for highly } \\
\text { skilled jobs } \\
\text { Important positive effect on } \\
\text { productivity, offsetting the } \\
\text { negative direct impact }\end{array}$ \\
\hline
\end{tabular}

Source: Prepared by the authors.

Studies at the company level analyse the effects of the offshoring of services on different variables including wages, productivity, and job type. Those referring only to the impact on employment include the studies by Gorg and Hanley (2005b), Hijzen et al. (2011), Liu and Trefler (2008), Crinò (2010), Harrison and McMillan (2011), Ottaviano et al. (2013), 
Sethupathy (2013), Moser et al. (2015), Ornaghi et al. (2017) and Eppinger (2017). In these studies the impact is estimated for different countries, obtaining, as in sectoral studies, different results for each (Table 2). Of these, Hijzen et al. (2007), Liu and Trifler (2008), Ornaghi et al. (2017) and Eppinger (2017) are focused on the impact of service offshoring on employment, in some cases with data of services and manufacturing companies and in others with data only of service companies. The rest of the studies are based solely on data of manufacturing companies.

Hijzen et al. (2007) estimate the impact on employment of offshoring services from the United Kingdom, with a sample of manufacturing and service companies. Using regression and propensity score matching techniques, the variation in total employment is estimated, which not only depends on imports but also the exports of services. A positive relationship is obtained between the imports of services and the growth of employment. This result can be explained by the fact that the companies that import the most are also those that export the most and these exports positively affect employment. Liu and Trefler (2008) focus their analysis entirely on services, on offshore outsourcing and only on low-wage trading. Using a regression framework, they estimate the impact on employment of offshoring from the United States to China and India and also of the inverse process called insourcing, which consists of the export of services from the United States to the afore-mentioned countries. The results obtained are small negative effects derived from the offshoring activities and small positive effects from inshoring, with a net positive effect in all cases. Ornaghi et al. (2017) estimate the effect of service offshoring on employment in Belgium based on a sample of manufacturing and service companies. Their estimate consists of regressing the growth of employment on timevarying firm-level measures of share of offshoring for goods and services, measured as imported goods or imported services over total turnover. The findings reveal that for the service sector there is a negative effect of service offshoring on the employment outcome of workers with higher levels of education. Finally, Eppinger (2017) estimates the effect of service offshoring on employment in companies in Germany based on a database of service companies that covers almost the entire universe of German firms' service imports with information on imports by country and type of service. The study investigates the firm-level employment effects of both new offshoring (the extensive margin) and changes in the volume of offshoring (the intensive margin). The former is analysed using a difference-in-differences matching approach, and the second using firm-specific export 
supply shocks by partner countries and service types in fixed effects regressions. The findings in all cases reveal positive effects on employment and indicate that the higher the starting level of offshoring, the greater these effects. The result is explained by the gains in competitiveness derived from offshoring activities to countries with lower costs and by the complementarity obtained between the foreign and national inputs and the resulting gains in productivity.

Table 2. Effects of Offshoring of Services on Employment Using Company Data

\begin{tabular}{|c|c|c|c|c|}
\hline Study & Country & Sample & Measure of Offshoring & Effect on Employment \\
\hline $\begin{array}{l}\text { Gorg and Hanley } \\
(2005 b)\end{array}$ & Ireland & $\begin{array}{l}100 \text { companies } \\
\text { Electronics industry } \\
1990-1995\end{array}$ & $\begin{array}{l}\text { Ratio of imported service } \\
\text { inputs to total non-energy } \\
\text { inputs }\end{array}$ & Negative, significant \\
\hline Hijzen et al. (2011) & UK & $\begin{array}{l}19114 \text { companies } \\
\text { Manufacturing and } \\
\text { service industries } \\
\text { 1997-2004 }\end{array}$ & $\begin{array}{l}\text { Service Exports and } \\
\text { Imports }\end{array}$ & Positive \\
\hline $\begin{array}{l}\text { Liu and Trefler } \\
\text { (2008) }\end{array}$ & U.S & $\begin{array}{l}96 \text { professional } \\
\text { service categories } \\
1996-2006\end{array}$ & $\begin{array}{l}\text { Offshoring.: Services } \\
\text { imported from China and } \\
\text { India } \\
\text { Inshoring: Services sold } \\
\text { to China and India }\end{array}$ & $\begin{array}{l}\text { Negative offshoring effect } \\
\text { Positive inshoring effect } \\
\text { Positive net effect }\end{array}$ \\
\hline Crinò (2010) & Italy & $\begin{array}{l}3079 \text { companies } \\
\text { Manufacturing } \\
\text { industry } \\
2001-2003\end{array}$ & $\begin{array}{l}\text { Service subject to a } \\
\text { offshoring based on report } \\
\text { with surveys of } \\
\text { companies containing this } \\
\text { question }\end{array}$ & $\begin{array}{l}\text { Positive impact on skilled } \\
\text { employment for services }\end{array}$ \\
\hline $\begin{array}{l}\text { Harrison and } \\
\text { McMillan (2011) }\end{array}$ & U.S. & $\begin{array}{l}\text { Manufacturing } \\
\text { industry } \\
1982-1999\end{array}$ & $\begin{array}{l}\text { Workforce hired by } \\
\text { multinationals at their } \\
\text { affiliates abroad }\end{array}$ & $\begin{array}{l}\text { The effect depends on both } \\
\text { the type and the location of } \\
\text { foreign investment. Only } \\
\text { for firms most likely to } \\
\text { perform the same tasks in } \\
\text { foreign affiliates and at } \\
\text { home is there a very small } \\
\text { negative impact on } \\
\text { domestic employment. }\end{array}$ \\
\hline $\begin{array}{l}\text { Ottaviano et al. } \\
\text { (2013) }\end{array}$ & U.S. & $\begin{array}{l}58 \text { manufacturing } \\
\text { industries } \\
2000-2007\end{array}$ & $\begin{array}{l}\text { Workforce hired by } \\
\text { multinationals at their } \\
\text { affiliates abroad }\end{array}$ & $\begin{array}{l}\text { Positive impact on } \\
\text { domestic employment } \\
\text { (+ve effect on productivity) }\end{array}$ \\
\hline Sethupathy (2013) & U.S. & $\begin{array}{l}\text { Manufacturing } \\
\text { industry } \\
1993-1997\end{array}$ & $\begin{array}{l}\text { Workforce hired by } \\
\text { multinationals at their } \\
\text { affiliates in Mexico }\end{array}$ & $\begin{array}{l}\text { No evidence of negative } \\
\text { impact on domestic } \\
\text { employment } \\
\text { (+ve effect on productivity }\end{array}$ \\
\hline Moser et al. (2015) & Germany & $\begin{array}{l}\text { Companies from } 16 \\
\text { manufacturing } \\
\text { industries } \\
1998-2004\end{array}$ & $\begin{array}{l}\text { Ratio of total intermediate } \\
\text { inputs to company total }\end{array}$ & $\begin{array}{l}\text { Considerable heterogeneity } \\
\text { across firms. Offshoring } \\
\text { firms creates more } \\
\text { employment than non- } \\
\text { offshoring firms. } \\
\text { Productivity increase } \\
\text { dominate and the overall }\end{array}$ \\
\hline
\end{tabular}




\begin{tabular}{|l|l|l|l|l|}
\hline & & & & $\begin{array}{l}\text { effect on employment is } \\
\text { positive }\end{array}$ \\
\hline $\begin{array}{l}\text { Ornaghi } \text { et al. } \\
(2017)\end{array}$ & Belgium & $\begin{array}{l}3751 \text { manufacturing } \\
\text { firms } \\
3679 \text { service firms } \\
1996-2005\end{array}$ & $\begin{array}{l}\text { Imported services over } \\
\text { total turnover }\end{array}$ & $\begin{array}{l}\text { Very small negative impact } \\
\text { on service employment } \\
\text { among highly educated } \\
\text { workers }\end{array}$ \\
\hline \multirow{2}{*}{ Eppinger, P. (2017) } & Germany & $\begin{array}{l}\text { Panel dataset of } \\
\text { firms'service } \\
\text { imports } \\
\text { 2001-2013 }\end{array}$ & $\begin{array}{l}\text { Imports of tradable } \\
\text { commercial services }\end{array}$ & $\begin{array}{l}\text { Positive effects that grow } \\
\text { with the level of offshoring }\end{array}$ \\
& & & \\
\hline
\end{tabular}

Source: Prepared by the authors.

Lastly, among the descriptive studies, it is worth highlighting those by Rishi and Saxena (2004), and Kirkegaard (2007) (Table 3). In both cases the analysis is based on the description of the evolution of the employment data in relation to the service offshoring operations carried out by the United States and the EU-15. This information is obtained through different statistical sources of these countries and the analysis of the results of previous publications by other authors. For the period between 2000 and 2002, Rishi and Saxena (2004) observe a loss of employment in the nine categories of services most typically offshored (related to IT), but forecast a long-term positive trend based on the hypothesis of an increased competitiveness that should be generated by the strategy. Finally, Kirkegaard (2007) carries out the same analysis for the period 2004-2005. Significant negative impacts on employment are observed: 18.1 per cent for the USA and 19.2 per cent for the EU-15.

Table 3. Descriptive Studies on the Relationship between Offshoring of Services and Employment

\begin{tabular}{|c|c|c|c|c|}
\hline Study & Country & Sample & Measure of Offshoring & Effect on Employment \\
\hline $\begin{array}{l}\text { Rishi and Saxena } \\
\text { (2004) }\end{array}$ & U.S & $\begin{array}{l}\text { Employment and } \\
\text { other national } \\
\text { statistics for the } \\
\text { service sector } \\
2000-2002\end{array}$ & Service imports and exports & $\begin{array}{l}\text { Short-term job losses. } \\
\text { Long-term job gains. } \\
\text { Net Positive effect }\end{array}$ \\
\hline Kirkegaard (2007) & $\begin{array}{l}\text { U.S. and } \\
\text { EU-15 }\end{array}$ & $\begin{array}{l}\text { Employment and } \\
\text { other national } \\
\text { statistics for the } \\
\text { service sector } \\
\text { 2004-2005 }\end{array}$ & Service imports and exports & $\begin{array}{l}\text { Negative: } \\
18.1 \% \text { - U.S. } \\
19.2 \% \text { - EU-15 }\end{array}$ \\
\hline
\end{tabular}




\section{Definition and Measurement of the Offshoring of Services}

Feenstra and Hanson $(1996,1999)$ were the first to define the offshoring index as the ratio of imported inputs to the total inputs used. However, the offshoring index most widely used in the empirical literature is the ratio of imported inputs to production value ${ }^{3}$. This indicator will be used in this study in order to measure the dependence on the imported services of each of the service types.

$$
\mathrm{BO}_{\mathrm{jt}}=\frac{\sum_{\mathrm{i}=1}^{\mathrm{n}} \mathrm{II}_{\mathrm{jit}}}{\mathrm{Y}_{\mathrm{jt}}} \quad \mathrm{j}=1, \ldots, \mathrm{J} ; \mathrm{i}=1, \ldots, \mathrm{I}
$$

where $\mathrm{BO}_{\mathrm{jt}}$ is the broad offshoring index for sector $\mathrm{j}$ in year $\mathrm{t}$; $\mathrm{I}_{\mathrm{jit}}$ the intermediate inputs imported by sector $\mathrm{j}$ from sector $\mathrm{i}$ in year $\mathrm{t}$; and $\mathrm{Y}_{\mathrm{jt}}$ the production value of sector $\mathrm{j}$ in year t.

This measurement of offshoring, which refers to the total intermediate services imported, both in the same sector and in the rest of services, is known as broad offshoring (BO). However, it is also useful to determine whether the intermediate services imported by each sector belong to the same branch of activity or to others. In this sense, intra-sectoral offshoring, also known as narrow offshoring is distinguished from inter-sectoral offshoring. Broad offshoring is the sum of the two and represents the total dependence on imported inputs.

Intra-sectoral offshoring or narrow offshoring (NO), first defined by Feenstra and Hanson (1999), measures the dependence on imported inputs from the same branch of activity and is expressed as:

$$
\mathrm{NO}_{\mathrm{jt}}=\frac{\mathrm{II}_{\mathrm{jjt}}}{\mathrm{Y}_{\mathrm{jt}}} \quad \mathrm{j}=1, \ldots, \mathrm{J}
$$

where $\mathrm{NO}_{\mathrm{jt}}$ is the narrow offshoring index for sector $\mathrm{j}$ in year $\mathrm{t}$; $\mathrm{II}_{\mathrm{jjt}}$ the total inputs used by sector $\mathrm{j}$ from the same sector $\mathrm{j}$ in year $\mathrm{t}$; and $\mathrm{Y}_{\mathrm{jt}}$ the production value of sector $\mathrm{j}$ in year t.

\footnotetext{
${ }^{3}$ See Campa and Goldberg (1997), Cardaso et al. (2008, 2012), and Michel and Rycx (2012).
} 
The empirical study reveals a rising trend in the offshoring of services by service companies over the 2000-2007 period (Graph 1), indicating that such companies are increasing the imports of intermediate service inputs per unit of production. The upward trend in the offshoring of services based on the broad index (33.7\% rise between 2000 and 2007) becomes even more marked when the narrow index is calculated $(42.15 \%$ increase $)^{4}$.

Graph 1: Trend in Broad, Narrow (intra-sectoral) and Inter-sectoral Offshoring of Services

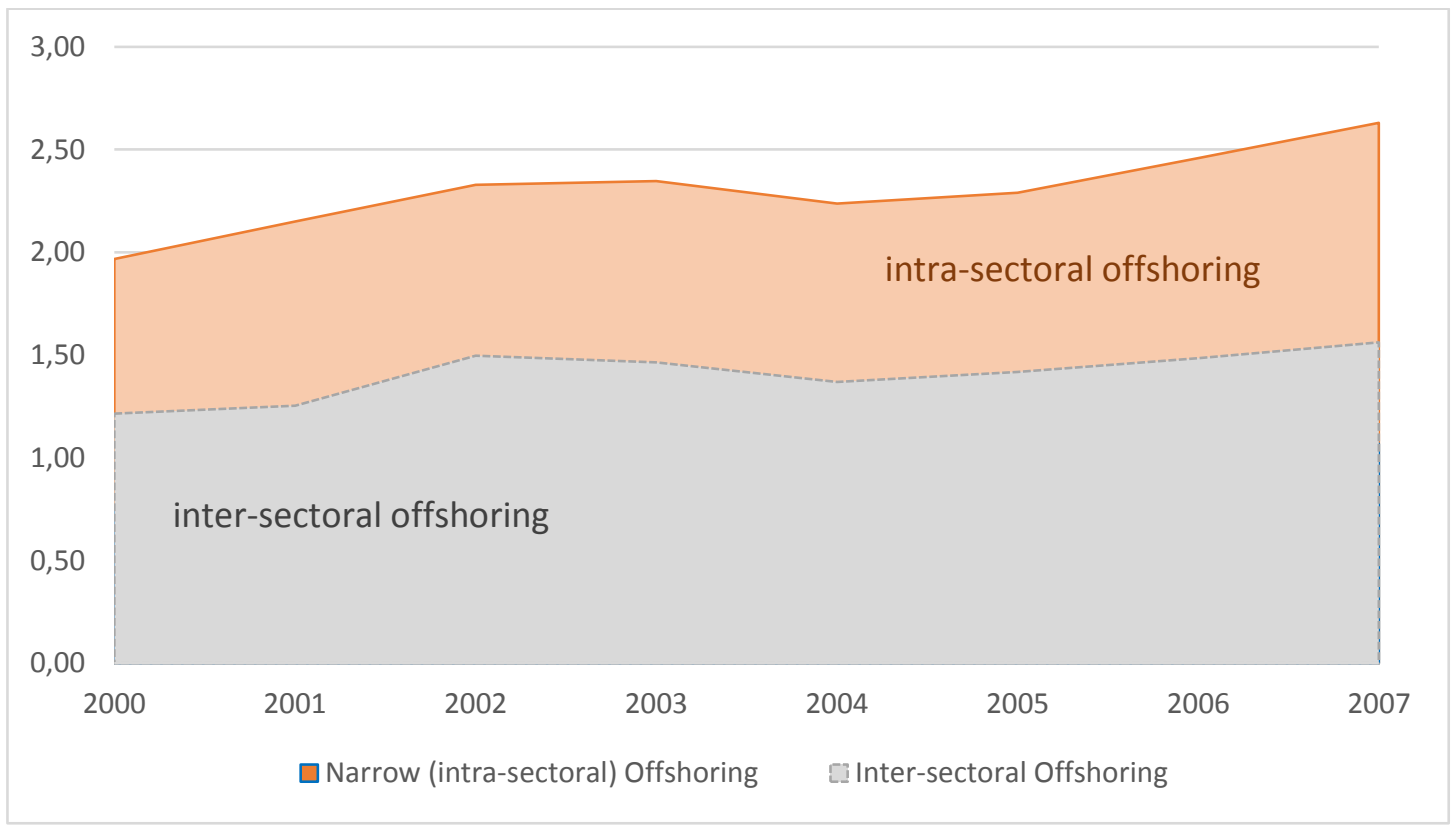

Note: The sum of the two offshoring indicators (intra-sectoral and inter-sectoral) gives us broad offshoring index, a measure of the total dependency on imported intermediate services relative to the production value.

Source: Prepared by the authors from Input-Output Tables, Spanish National Accounts, INE.

With respect to offshoring by different service sectors, the activities showing the highest dependency on imported intermediate services relative to the production value (broad offshoring) are Travel Agency activities, Maritime transport and Air transport. These are followed by Insurance and pension plans, Recreational, cultural and sports market activities, Wholesale trade and intermediaries, Ancillary activities, IT activities, Financial trading, Postal and telecommunications services, and Transport-related

\footnotetext{
${ }^{4}$ A more detailed study of the results of offshoring of services indices for the Spanish economy can be found in Fuster and Martínez-Mora (2013).
} 
activities. Most of these activities are those with the highest narrow offshoring indices, i.e., they show a high dependency on intra-sectoral intermediate service imports, except for Maritime transport (Table 4).

Table 4: Broad, Narrow and Inter-sectoral Offshoring of Services

\begin{tabular}{|c|c|c|c|c|c|c|c|}
\hline & \multicolumn{4}{|c|}{ Offshoring Index, 2007} & \multicolumn{3}{|c|}{$\begin{array}{l}\text { Percentage Difference, } \\
\text { 2000-2007 }\end{array}$} \\
\hline & \multirow{2}{*}{$\begin{array}{l}\text { BO } \\
\text { Index }\end{array}$} & \multicolumn{2}{|c|}{ NO (Intra-sectoral) } & \multirow{2}{*}{$\begin{array}{l}\text { Inter- } \\
\text { sectoral } \\
\text { Index }\end{array}$} & \multirow[t]{2}{*}{$\mathrm{BO}$} & \multirow[t]{2}{*}{$\mathrm{NO}$} & \multirow{2}{*}{$\begin{array}{l}\text { Inter- } \\
\text { sectoral }\end{array}$} \\
\hline & & Index & $\begin{array}{l}\text { Percentage } \\
\text { of BO }\end{array}$ & & & & \\
\hline Travel agency activities & 23.70 & 6.45 & 27.20 & 17.25 & 7.66 & 5.12 & 2.54 \\
\hline Maritime transport & 22.15 & 0.00 & 0.00 & 22.15 & 8.73 & 0.00 & 8.73 \\
\hline Air transport & 17.38 & 1.62 & 9.30 & 15.76 & -4.80 & 0.35 & -5.15 \\
\hline Insurance and pension plans & $7, .9$ & 4.23 & 55.04 & 3.46 & 2.41 & 3.99 & -1.58 \\
\hline $\begin{array}{l}\text { Recreational, cultural and sports market } \\
\text { activities }\end{array}$ & $6, .95$ & 5.61 & 80.65 & 1.35 & -1.24 & -0.27 & -0.97 \\
\hline Wholesale trade and intermediaries & 6.60 & 0.39 & 5.91 & 6.21 & 5.48 & -0.02 & 5.50 \\
\hline Ancillary activities & 6.50 & 5.30 & 81.52 & 1.20 & 4.97 & 5.30 & -0.33 \\
\hline IT activities & 5.16 & 0.27 & 5.14 & 4.90 & 2.12 & -0.87 & 2.99 \\
\hline Financial trading & 5.07 & 2.98 & 58.81 & 2.09 & 0.12 & 1.58 & -1.46 \\
\hline Postal and telecommunications services & 4.98 & 3.96 & 79.46 & 1.02 & 1.40 & 1.20 & 0.20 \\
\hline Transport-related activities & 4.94 & 4.54 & 91.82 & 0.40 & -0.01 & 1.2 & -1.21 \\
\hline Market research and development & 3.07 & 0,00 & 0.00 & 3.07 & 2.42 & 0.00 & 2.42 \\
\hline Other business activities & 2.72 & 2.35 & 86.18 & 0.38 & -0.99 & -0.08 & -0.91 \\
\hline Non-market association activities & 2.42 & 0.00 & 0.00 & 2.42 & 1.20 & 0.00 & 1.20 \\
\hline Accommodation & 1.97 & 0.00 & 0.00 & 1.97 & -0.12 & 0.00 & -0.12 \\
\hline Machinery and domestic item rental & 1.54 & 0.00 & 0.00 & 1.54 & 1.26 & 0.00 & 1.26 \\
\hline Retail trade; personal item repair & 1.31 & 0.00 & 0.00 & 1.31 & 0.85 & 0.00 & 0.85 \\
\hline Railway transport & 1.22 & 0.00 & 0.00 & 1.22 & 0.50 & 0.00 & 0.50 \\
\hline $\begin{array}{l}\text { Motor vehicle sale and repair; automotive } \\
\text { fuel trading }\end{array}$ & 1.05 & 0.24 & 23.36 & 0.80 & 0.83 & 0.24 & 0.59 \\
\hline Market association activities & 0.94 & 0.00 & 0.00 & 0.94 & -0.03 & 0.00 & -0.03 \\
\hline Overland transport and pipeline transport & 0.94 & 0.00 & 0.02 & 0.94 & 0.33 & 0.00 & 0.33 \\
\hline Public administration & 0.70 & 0.00 & 0.00 & 0.70 & 0.19 & 0.00 & 0.19 \\
\hline Public sanitation market activities & 0.69 & 0.00 & 0.00 & 0.69 & 0.61 & 0.00 & 0.61 \\
\hline Real estate activities & 0.54 & 0.00 & 0.00 & 0.54 & 0.27 & 0.00 & 0.27 \\
\hline $\begin{array}{l}\text { Recreational and cultural non-market } \\
\text { activities }\end{array}$ & 0.40 & 0.00 & 0.00 & 0.40 & 0.39 & 0.00 & 0.39 \\
\hline Education market activities & 0.18 & 0.00 & 0.00 & 0.18 & 0.09 & 0.00 & 0.09 \\
\hline $\begin{array}{l}\text { Healthcare and social services non-market } \\
\text { activities }\end{array}$ & 0.16 & 0.00 & 0.00 & 0.16 & 0.04 & 0.00 & 0.04 \\
\hline Education non-market activities & 0.11 & 0.00 & 0.00 & 0.11 & 0.09 & 0.00 & 0.09 \\
\hline Miscellaneous personal service activities & 0.09 & 0.03 & 37.50 & 0.05 & -0.74 & 0.03 & -0.77 \\
\hline $\begin{array}{l}\text { Healthcare and social services market } \\
\text { activities }\end{array}$ & 0.07 & 0.00 & 0.00 & 0.07 & -0.05 & 0.00 & -0.05 \\
\hline Restaurants and catering & 0.02 & 0.00 & 0.00 & 0.02 & -0.04 & 0.00 & -0.04 \\
\hline $\begin{array}{l}\text { Public sanitation non-market activities by } \\
\text { Public Administrations }\end{array}$ & 0.00 & 0.00 & - & 0.00 & 0.00 & 0.00 & 0.00 \\
\hline Households employing domestic help & 0.00 & 0.00 & - & 0.00 & 0.00 & 0.00 & 0.00 \\
\hline
\end{tabular}




\begin{tabular}{|l|l|l|l|l|l|l|l|}
\hline Total Services & 2.63 & 1.07 & 40.62 & 1.56 & 0.26 & 0.32 & -0.05 \\
\hline
\end{tabular}

BO: Broad Offshoring; NO: Narrow Offshoring. Industries listed from higher to lower broad offshoring index in 2007.

Note: NO represents the intra-sectoral index and refers to the dependency on intermediate services imported from the same sector of activity relative to the production value, and inter-sectoral index refers to the dependency on intermediate services from other service sectors relative to the production value. The sum of the two indicators gives us the BO index, a measure of the total dependency on imported intermediate services relative to the production value (II/Y).

Source: Prepared by the authors from Input-Output Tables, Spanish National Accounts, INE.

In dynamic terms, the growing importance of the offshoring of services can be observed. This can be explained by a greater dependency on imported intra-sectoral services. The service sectors showing the highest offshoring increases were Maritime transport, Travel agency activities, Wholesale trade and intermediaries, Ancillary activities, Market research and development, Insurance and pension plans, IT activities, Postal and telecommunications services, and Machinery and domestic item rental. The greater dependency on imported services observed in some of these sectors (Ancillary activities, Travel agency activities, Insurance and pension plans, and Postal and telecommunications services) can be explained by the intra-sectoral component, whereas for the rest of the sectors only the dependency on imported inter-sectoral services was found to increase (Table 4).

\section{4.- Offshoring of services: effects on employment}

As previously indicated, the theoretical forecasts regarding the impact of offshoring on employment are ambiguous, with possible different effects in the medium and long term.

In this study, an empirical analysis of said impact over the 2000-2007 period of expansion has been carried out for the Spanish service industry, sourcing the data from the InputOutput tables of the Spanish National Accounts published by the Spanish National Statistics Institute (INE) for that period.

In line with previous research ${ }^{5}$, we have used a log-linear labour demand function derived from a homogeneous production function with constant returns to scale (CES),

\footnotetext{
${ }^{5}$ See Crinó (2010), Wright (2014), Michel and Rycx (2012), Agnese (2012), and Cadarso (2008, 2012).
} 
(Hamermesh, 1993), in which the offshoring of services is also included as an explanatory variable.

$$
\begin{aligned}
& L_{i}=\beta_{0}+\beta_{1} Y_{i}+\beta_{2} w_{i}+\beta_{3} O S_{i}+v_{i} \\
& i=1 \ldots . n \text {, where } n \text { is the number of observations. }
\end{aligned}
$$

Where $L i$ is total employment in logarithms; wi the average wage in logarithms; $Y i$ the production value in logarithms; OSi the offshoring index calculated as the ratio of imported inputs to the production value and $v_{i}$ the random disturbance.

According to economic theory, the estimated value of coefficient $\beta_{2}$, labour-employment price elasticity, should take a negative sign, while the sign of $\beta_{1}$, production-employment elasticity, should be positive. As regards the estimated coefficient associated with offshoring, $\beta_{3}$, offshoring is not estimated in logarithms ${ }^{6}$, as in Wright (2014) and Agnese (2012). In this case, the coefficient obtained, $\beta_{3}$, is interpreted as employment elasticity relative to offshoring, our aim being to determine its significance, value and size.

Moreover, in order to compare the effect on employment of the inclusion of the offshoring of services and of the offshoring components analysed - narrow (intra-industry) and interindustry - the following regressions have been estimated for the period considered:

(1) a labour demand function including broad offshoring (BO), both inter-sectoral and intra-sectoral, as a regressor.

(2) a labour demand function including intra-sectoral or narrow offshoring (NO) as the explanatory variable.

(3) a labour demand function including inter-sectoral offshoring (IO) as the explanatory variable.

A description is given below of the different estimations and models used for the analysis.

\footnotetext{
${ }^{6}$ In order not to miss any observations, as 168 have an offshoring value $=0$.
} 


\section{1-Panel Data Model: Fixed Effects}

The estimations have been carried out using a panel data model for the eight periods analysed $(\mathrm{T}=8)$ and the thirty-five service subsectors considered $(\mathrm{N}=35), \mathrm{N}=35>\mathrm{T}=8$.

This longitudinal data analysis enables us to study the variables of interest over time for the same elements of the sample, in our case the subsectors of the service industry; the panel is balanced as $\mathrm{T}$ is 8 periods for all the subsectors analysed.

The CES demand function now considered is:

$$
\begin{aligned}
& L_{i t}=\beta_{0}+\beta_{1} Y_{i t}+\beta_{2} w_{i t}+\beta_{3} O S_{i t}+\left(e i+u_{i t}\right) \\
& i=1 \ldots . . N \\
& t=1 \ldots . T
\end{aligned}
$$

Where $i$ refers to the subsector considered $\mathrm{N}$, and $t$ refers to the period analysed $\mathrm{T}$; the random disturbance, vi, is decomposed into two effects: $e$, unobservable time-invariant differences between subsectors, and uit, a purely random term.

Where Lit $=$ Total employment in logarithms; wit $=$ average wage in logarithms; $Y i t=$ production value in logarithms; and $O S i t=$ Offshoring, whose effect is broken down into the three regressions considered: (1), (2) and (3), considering broad offshoring (BO), narrow or intra-industry offshoring (NO), and inter-industry offshoring (IO), respectively.

Having confirmed the convenience of using a panel model ${ }^{7}$, the question then arose regarding whether the fixed effect approach might be more robust, as it is not dependent on additional assumptions, although it could also be less accurate than the random effect approach. To resolve this issue, we carried out a Hausman's test ${ }^{8}$ and found that, in our

\footnotetext{
${ }^{7}$ The Breusch Pagan test, a Lagrange multiplier for random effects, indicates that the random effect model is more appropriate than an aggregated cross-sectional model, while the F-test shows that a fixed effect model is better than the aggregate model, thus confirming that the nested data model improves the accuracy of estimation relative to a cross-sectional pool.

${ }^{8}$ Hausman (1978) proposes the null hypothesis that the fixed and random effect coefficients do not show systematic differences; if we discard the Ho, the fixed effect approach is more appropriate, while the random effect model would be more suitable if we accept it.
} 
case, differences exist between fixed and random effect estimations, indicating the advisability of using the fixed effect model. This is why we have presented the fixedeffect estimations.

The results of these estimations are shown in Table 5 (1) (2) and (3). In all cases, it may be observed that offshoring has a very small, non-significant negative effect on employment in the service industry. The production-employment and wage-employment elasticities continue to take the expected signs.

In the same way as Michel and Rycx (2012), in the fixed effect model we have included the explanatory variables lagged by one period to capture their possible effect. As also pointed out by Amiti and Wei (2005), it should be taken into account that the effects on employment could be non-immediate.

$$
L_{i t}=\beta_{0}+\beta_{1} Y_{i t}+\beta_{2} Y_{i t-1}+\beta_{3} w_{i t}++\beta_{4} w_{i t-1}+\beta_{5} O S_{i t}+\beta_{6} O S_{i t-1}+\left(e i+u_{i t}\right)
$$

In these estimations (1 $)\left(2^{\prime}\right)$ and $\left(3^{\prime}\right)$ we find that the offshoring coefficients are again non-significant, very small in size, and continue to take a negative sign, also when lagged. We can also observe an increase in the elasticities derived from the output and wage coefficients, relative to the non-lagged fixed effect model, again with the expected signs.

Michel and Rycx (2012) also include dynamic effects in the fixed effect model ${ }^{9}$. Table 5, (1") (2") (3"), shows the results of including an autoregressive element of the dependent variable in the fixed effect model, which allows us to consider that the labour demand in year $t$ depends on the labour demand in the previous year $t-1$, in addition to including the other explanatory variables considered and their lags.

In this model, the offshoring coefficients are still very small, take a negative sign and are non-significant, yielding results consistent with the previous ones and revealing no major

\footnotetext{
${ }^{9}$ As indicated by these authors, introducing the lagged dependent variable in the regression enables the persistence of the employment level to be taken into account.
} 
losses in employment due to offshoring according to the panel models. The productionemployment elasticities are smaller than for the non-lagged model (Table 5, (1) (2) and (3)) while the wage elasticities are larger, both of them taking the expected sign. Moreover, the lagged variables of these elasticities are significant, as is the employment for the previous period.

Table 5: Estimated Labour Demand: Fixed Effects and lagged variables

\begin{tabular}{|c|c|c|c|c|c|c|c|c|c|}
\hline & (1) & (2) & (3) & $\left(1^{\prime}\right)$ & $\left(2^{\prime}\right)$ & $\left(3^{\prime}\right)$ & (1") & (2") & (3") \\
\hline \multirow[t]{2}{*}{$\operatorname{Ln} Y$} & $0.619^{*}$ & $0.618 * *$ & $0.613 * *$ & $0.777 * *$ & $0.785 * *$ & $0.778^{* * *}$ & $0.585 * *$ & $0.583 * *$ & $0.583^{* *}$ \\
\hline & $(0.293)$ & $(0.032)$ & $(0.294)$ & $(0.312)$ & $(0.318)$ & $(0.312)$ & $(0.278)$ & $(0.318)$ & $(0.277)$ \\
\hline \multirow[t]{4}{*}{ Ln Yt-1 } & & & & -0.062 & -0.075 & -0.073 & - & - & $-0.380 * *$ \\
\hline & & & & & & & $0.380 * *$ & $0.382 * * *$ & \\
\hline & & & & $(0.190)$ & $(0.211)$ & $(0.190)$ & & & $(0.185)$ \\
\hline & & & & & & & $(0.185)$ & $(0.203)$ & \\
\hline \multirow[t]{2}{*}{ Ln w } & $-0.863 *$ & $-0.872 *$ & $-0.867 *$ & $-1.121 *$ & $-1.110^{*}$ & $-1.115^{*}$ & $-1.038 *$ & $-1.038^{*}$ & $-1.041 *$ \\
\hline & $(0.309)$ & $(0.319)$ & $(0.311)$ & $(0.195)$ & $(0.188)$ & $(0.201)$ & $(0.261)$ & $(0.263)$ & $(0.201)$ \\
\hline \multirow[t]{2}{*}{ Ln w t-1 } & & & & 0.208 & 0.188 & 0.196 & $0.774 *$ & $0.772 *$ & $0.776^{*}$ \\
\hline & & & & $(0.180)$ & $(0.188)$ & $(0.177)$ & $(0.197)$ & $(0.194)$ & (0.197) \\
\hline \multirow[t]{2}{*}{$\mathrm{BO}$} & -0.003 & & & -0.001 & & & -0.001 & & \\
\hline & $(0.005)$ & & & $(0.002)$ & & & $(0.002)$ & & \\
\hline \multirow[t]{2}{*}{ BOt-1 } & & & & -0.004 & & & -0.001 & & \\
\hline & & & & $(0.004)$ & & & $(0.001)$ & & \\
\hline \multirow[t]{2}{*}{ NO } & & -0.007 & & & -0.002 & & & -0.001 & \\
\hline & & (0.009) & & & $(0.008)$ & & & $(0.038)$ & \\
\hline \multirow[t]{2}{*}{ NO t-1 } & & & & & -0.006 & & & -0.000 & \\
\hline & & & & & $(0.010)$ & & & $(0.034)$ & \\
\hline \multirow[t]{2}{*}{ IO } & & & -0.002 & & & -0.000 & & & -0.001 \\
\hline & & & $(0.007)$ & & & $(0.002)$ & & & $(0.003)$ \\
\hline \multirow[t]{2}{*}{ IO t-1 } & & & & & & -0.003 & & & -0.001 \\
\hline & & & & & & $(0.004)$ & & & $(0.001)$ \\
\hline \multirow[t]{2}{*}{ Ln Lt-1 } & & & & & & & $0.775^{*}$ & $0.777 *$ & $0.776^{*}$ \\
\hline & & & & & & & (0.049) & $(0.050)$ & (0.049) \\
\hline \multirow[t]{2}{*}{ Constant } & 1.980 & 2.025 & 2.034 & 1.284 & 1.361 & 1.385 & 0.095 & 1.119 & 1.060 \\
\hline & (2.335) & (2.397) & $(2.347)$ & (2.710) & (2.809) & $(2.720)$ & $(0.897)$ & $(0.893)$ & (0.883) \\
\hline $\mathrm{R}^{2}$ & 0.838 & 0.840 & 0.845 & 0.849 & 0.841 & 0.846 & 0.993 & 0.993 & 0.994 \\
\hline $\mathrm{n}$ & 280 & 264 & 280 & 245 & 231 & 245 & 245 & 231 & 245 \\
\hline
\end{tabular}

Significant at 1\%; **Significant at 5\%;***Significant at 10\%. All specifications include control variables for the year of the survey. Robust standard errors in brackets. Note: Dependent employment level variable in logs. 
The offshoring of services may initially be expected to have a short-term job destruction effect in this industry in Spain. However, the results obtained with the panel models used indicate that the medium-term gains in efficiency and competitiveness of the companies carrying out such offshoring could lead to a rise in domestic job creation and output that would offset the losses, although they would not have a net positive impact on employment.

\section{2.-Differences in differences}

In order to test the robustness of our estimates, we have used a first- and second-difference fixed effect model, so that the demand equation includes a fixed effect that changes over time.

Following Amiti and Wei (2005), the first difference equation [3] is transformed as:

$$
\Delta L_{i t}=\beta_{1 \Delta} Y_{i t}+\beta_{2 \Delta} Y_{i t-1}+\beta_{3} \Delta w_{i t}+{ }_{+} \beta_{4} \Delta w_{i t-1}+\beta_{5} \Delta O S_{i t}+\beta_{6} \Delta O S_{i t-1}+\varepsilon_{i t}
$$

Where $\Delta$ is the change, so that, $\Delta X=X t-X t-1$.

Where, $\Delta$ Lit $=$ change in total employment in logarithms; $\Delta$ wit $=$ change in average wage in logarithms; $\Delta Y i t=$ change in production value in logarithms; and $\triangle O S i t=$ change in offshoring. In the same way as the previous models, the effect of offshoring is decomposed into the three regressions considered, (1), (2) and (3), in this case considering $\Delta$ broad offshoring (BO), $\Delta$ narrow or intra-industry offshoring (NO), and $\Delta$ intraindustry offshoring (IO), respectively. 
Also shown in Table 6, (1') (2') (3'), are the results of the second-difference model ${ }^{10}$, considering two periods in order to also capture the possible productivity effect. Where $\Delta$ is the change, so that, $\Delta X=X t-X t-2$.

The elasticities are significant and take the expected signs and their value increases in the second difference model.

With regard to our variable of interest, namely offshoring and its components, all the specifications in the first difference model show a very small, non-significant effect of offshoring on the level of employment. In the second difference model, offshoring is seen to have a broad positive effect; narrow offshoring takes a negative sign, which becomes positive when the lag is considered; and the value for inter-sectoral offshoring is positive. All of these values are, again, very small and non-significant.

Based on first difference estimations, Amiti and Wei (2005) suggest that in the service industries, job displacement due to offshoring might be offset by new job creation in the same sector, which might likewise apply to the Spanish case for the expansive period considered.

Table 6: First and Second Difference Labour Demand Estimation

\begin{tabular}{|c|c|c|c|c|c|c|}
\hline & (1) & (2) & (3) & (1') & (2') & $\left(3^{\prime}\right)$ \\
\hline \multirow[t]{2}{*}{$\Delta \operatorname{Ln~Y}$} & $0.508 * * *$ & $0.512 * * *$ & $0.508 * * *$ & $0.685 * *$ & $0.702 * *$ & $0.688^{* *}$ \\
\hline & $(0.285)$ & $(0.292)$ & $(0.286)$ & $(0.275)$ & $(0.289)$ & $(0.276)$ \\
\hline \multirow[t]{2}{*}{$\Delta \mathrm{Ln} \mathrm{Yt-1}$} & 0.103 & 0.102 & 0.101 & 0.159 & 0.134 & 0.162 \\
\hline & (0.084) & $(0.093)$ & $(0.085)$ & $(0.154)$ & $(0.159)$ & $(0.153)$ \\
\hline \multirow[t]{2}{*}{$\Delta \mathrm{Ln} \mathrm{w}$} & $-0.927^{*}$ & $-0.934 *$ & $-0.926^{*}$ & $-1.075^{*}$ & $-1.091 *$ & $-1.076^{*}$ \\
\hline & $(0.266)$ & $(0.271)$ & $(0.267)$ & $(0.251)$ & $(0.257)$ & $(0.251)$ \\
\hline \multirow[t]{2}{*}{$\Delta \mathrm{Ln}$ w t- 1} & -0.038 & -0.037 & -0.040 & -0.192 & -0.203 & -0.196 \\
\hline & (0.077) & $(0.079)$ & $(0.077)$ & $(0.187)$ & $(0.189)$ & $(0.187)$ \\
\hline \multirow[t]{2}{*}{$\Delta \mathrm{BO}$} & -0.001 & & & 0.001 & & \\
\hline & (0.003) & & & $(0.003)$ & & \\
\hline$\Delta$ BOt-1 & -0.001 & & & 0.001 & & \\
\hline
\end{tabular}

\footnotetext{
${ }^{10}$ Longer lags were not included due to the limitations of panels that are not long (Griliches and Hausman, 1986); in our case $\mathrm{T}=8$ (eight years).
} 


\begin{tabular}{|c|c|c|c|c|c|c|}
\hline$\Delta \mathrm{NO}$ & \multicolumn{3}{|c|}{-0.003} & \multicolumn{3}{|c|}{-0.005} \\
\hline \multirow{3}{*}{$\Delta \mathrm{NO} t-1$} & & (0.004) & & & $(0.005)$ & \\
\hline & & -0.001 & & & 0.001 & \\
\hline & & (0.004) & & & $(0.006)$ & \\
\hline$\Delta \mathrm{IO}$ & & & -0.000 & & & 0.002 \\
\hline \multirow{3}{*}{$\Delta \mathrm{IO} \mathrm{t}-1$} & & & $(0.003)$ & & & $(0.003)$ \\
\hline & & & -0.001 & & & 0.001 \\
\hline & & & $(0.002)$ & & & $(0.002)$ \\
\hline Fixed effects & Year & Year & Year & Year & Year & Year \\
\hline$\overline{\mathrm{R}^{2}}$ & 0.606 & 0.602 & 0.606 & 0.433 & 0.438 & 0.434 \\
\hline $\mathrm{n}$ & 210 & 198 & 210 & 175 & 165 & 175 \\
\hline
\end{tabular}

Note: *Significant at $1 \%$; **Significant at $5 \%$; ***Significant at $10 \%$. All specifications include control variables for the year of the survey. Robust standard errors in brackets. Note: Difference model dependent employment level variable in logs.

Source: Prepared by the authors from the input-output tables (2000-2007), INE.

\section{3.- Dynamic model. Generalized Method of Moments (GMM)}

A potential problem of endogeneity associated with offshoring may arise due to the existence of a simultaneity relationship between employment decisions and offshoring decisions in the company: a rise in wages in the country of origin might lead to an increase in offshoring, which would, in theory, cause a fall in employment in the company's home country. Therefore, in order to incorporate a potential endogeneity factor we have first used a dynamic model proposed by Arellano and Bond (1991), namely a difference GMM (difference generalized method of moments), which uses as instruments the differences of the lags and includes the lagged dependent variable as a regressor. Furthermore, for panels with a short time period, as in our case, Arellano and Bover (1995) incorporate variables in levels using differences and levels as instruments, System GMM (systems generalized method of moments). The results of both methods are show in Table $7^{11}$.

\footnotetext{
${ }^{11}$ Using the Sargan test we have confirmed that the instruments used are valid. We have also confirmed, using the Arellano-Bond test, that there is no second-order serial autocorrelation.
} 
Table 7: Dynamic Labour Demand Estimation with GMM

\begin{tabular}{|c|c|c|c|c|c|c|}
\hline & \multicolumn{3}{|c|}{ DIFF GMM } & \multicolumn{3}{|c|}{ SYS GMM } \\
\hline & (1) & (2) & (3) & $\left(1^{\prime}\right)$ & (2') & (3') \\
\hline \multirow[t]{2}{*}{ Ln Lt-1 } & $0.548 * *$ & $0.498 * *$ & $0.545^{* *}$ & $0.501 * *$ & $0.472 * * *$ & $0.508 * *$ \\
\hline & $(0.219)$ & $(0.212)$ & (0217) & $(0.215)$ & $(0.251)$ & (0231) \\
\hline \multirow[t]{2}{*}{$\operatorname{Ln} Y$} & $0.456^{*}$ & $0.508^{*}$ & $0.458 *$ & $0.469 * *$ & $0.498 * *$ & $0.462 * *$ \\
\hline & $(0.166)$ & $(0.157)$ & $(0.164)$ & $(0.183)$ & $(0.213)$ & $(0.197)$ \\
\hline \multirow[t]{2}{*}{ Ln w } & $-0.646^{*}$ & $-0.720 *$ & $-0.646^{*}$ & $-0.672 *$ & $-0.736^{*}$ & $-0.668 *$ \\
\hline & $(0.198)$ & $(0.192)$ & $(0.196)$ & $(0.223)$ & $(0.241)$ & $(0.235)$ \\
\hline \multirow[t]{2}{*}{ BO } & 0.000 & & & -0.000 & & \\
\hline & $(0.001)$ & & & $(0.006)$ & & \\
\hline \multirow[t]{2}{*}{ NO } & & -0.001 & & & 0.001 & \\
\hline & & $(0.005)$ & & & $(0.011)$ & \\
\hline \multirow[t]{2}{*}{ IO } & & & -0.000 & & & 0.000 \\
\hline & & & $(0.001)$ & & & $(0.003)$ \\
\hline Sargan & 0.1899 & 0.2006 & 0.1948 & 0.6718 & 0.4743 & 0.6989 \\
\hline $\mathrm{AR}(1)$ & 0.3217 & 0.3699 & 0.3234 & 0.3338 & 0.4068 & 0.3380 \\
\hline $\mathrm{AR}(2)$ & 0.9759 & 0.9208 & 0.9787 & 0.9958 & 0.9170 & 0.9976 \\
\hline
\end{tabular}

*Significant at $1 \%$;* Significant at 5\%; ***Significant at $10 \%$. Robust standard errors in brackets. Note: Dependent employment level variable in logs.

We have also estimated the model with lagged variables (Table 8) with difference GMM and system $\mathrm{GMM}^{12}$.

12 Using the Sargan test, we have confirmed that the overidentification restrictions are valid and with the Arellano-Bond test that there is no second-order serial autocorrelation. 
Table 8: Dynamic Labour Demand Estimation with lagged variables, GMM

\begin{tabular}{|c|c|c|c|c|c|c|}
\hline & \multicolumn{3}{|c|}{ DIFF GMM } & \multicolumn{3}{|c|}{ SYS GMM } \\
\hline & (1) & (2) & (3) & (1') & $\left(2^{\prime}\right)$ & $\left(3^{\prime}\right)$ \\
\hline \multirow[t]{2}{*}{ LnLt-1 } & $0.673^{*}$ & $0.673^{*}$ & $0.668^{*}$ & $0.663^{*}$ & 0.694* & $0.667^{*}$ \\
\hline & $(0.169)$ & $(0.169)$ & $(0.155)$ & $(0.196)$ & $(0.188)$ & $(0.193)$ \\
\hline \multirow[t]{2}{*}{$\operatorname{Ln} Y$} & $0.474 * *$ & $0.474 * *$ & $0.458 * *$ & $0.595 * *$ & $0.611 *$ & $0.589 * *$ \\
\hline & $(0.209)$ & $(0.209)$ & $(0.190)$ & $(0.241)$ & $(0.256)$ & $(0.241)$ \\
\hline \multirow[t]{2}{*}{ Ln Yt-1 } & -0.223 & -0.223 & -0.211 & -0.278 & $-0.327 * * *$ & -0.280 \\
\hline & $(0.195)$ & $(0.195)$ & $(0.172)$ & $(0.181)$ & $(0.181)$ & $(0.179)$ \\
\hline \multirow[t]{2}{*}{ Ln w } & $-0.781 *$ & $-0.781^{*}$ & $-0.756^{*}$ & $-0.975^{*}$ & $-0.940 *$ & $-0.978 *$ \\
\hline & $(0.218)$ & $(0.218)$ & $(0.213)$ & $(0.232)$ & $(0.232)$ & $(0.232)$ \\
\hline \multirow[t]{2}{*}{ Ln w t-1 } & $0.513^{*}$ & $0.513 *$ & $0.503^{*}$ & $0.538 *$ & $0.501 * *$ & $0.550^{*}$ \\
\hline & $(0.107)$ & $(0.107)$ & $(0.099)$ & $(0.181)$ & $(0.221)$ & $(0.171)$ \\
\hline \multirow[t]{2}{*}{$\mathrm{BO}$} & 0.001 & & & -0.003 & & \\
\hline & $(0.001)$ & & & $(0.003)$ & & \\
\hline \multirow[t]{2}{*}{ BOt-1 } & 0.001 & & & -0.002 & & \\
\hline & $(0.001)$ & & & $(0.005)$ & & \\
\hline \multirow[t]{2}{*}{ NO } & & -0.001 & & & 0.002 & \\
\hline & & $(0.001)$ & & & $(0.007)$ & \\
\hline \multirow[t]{2}{*}{ NO t-1 } & & 0.001 & & & 0.004 & \\
\hline & & $(0.003)$ & & & $(0.006)$ & \\
\hline \multirow[t]{2}{*}{ IO } & & & -0.001 & & & -0.003 \\
\hline & & & $(0.001)$ & & & $(0.003)$ \\
\hline \multirow[t]{2}{*}{ IO t-1 } & & & -0.001 & & & -0.002 \\
\hline & & & $(0.001)$ & & & $(0.005)$ \\
\hline Sargan & 0.1318 & 0.1743 & 0.1369 & 0.1700 & 0.1021 & 0.2058 \\
\hline $\operatorname{AR}(1)$ & 0.1845 & 0.1718 & 0.1795 & 0.0264 & 0.0182 & 0.0253 \\
\hline $\operatorname{AR}(2)$ & 0.4267 & 0.4257 & 0.4184 & 0.4242 & 0.4495 & 0.4265 \\
\hline
\end{tabular}

*Significant at $1 \%$; **Significant at 5\%; ***Significant at $10 \%$. Robust standard errors in brackets. Note: Dependent employment level variable in logs.

The results of Tables 7 and 8 once again show that offshoring has a very small and nonsignificant impact on employment in services as we have seen in the fixed-effects model. 


\section{CONCLUSIONS}

The growing importance of offshoring, together with the criticism increasingly faced by this strategy as an alleged cause of domestic job losses, justifies the need for analysing both the extent to which Spanish service industries are sourcing intermediate services from other countries and the impact of this strategy on domestic employment in the service sector.

The results reveal that between 2000 and 2007 the Spanish economy showed a growing dependency on intermediate services imported by the service sector. This rising trend in service imports by unit product is mainly driven by the intra-sectoral component.

The sectoral analysis reveals that, in aggregate terms, the service subsectors import intermediate services both from the same subsector (intra-sectoral) and from other subsectors (inter-sectoral). The activities showing the highest levels of dependency on intermediate service imports relative to their production value are Travel agency activities and Maritime transport. Moreover, the subsectors where most imports per unit product are intra-sectoral are Transport-related activities, Other business activities, Ancillary activities, Recreational, cultural and sports market activities, Postal and Telecommunications services, Financial trading, and Insurance and retirement plans.

From a dynamic perspective, the subsectors showing a significant rise in dependency include Ancillary activities, Travel agency activities, Insurance and pension plans and Postal and telecommunications services, mainly driven by intra-sectoral intermediate services. On the other hand, for Maritime transport, Market research and development, Machinery and household item rental and IT activities only the dependency on intersectoral service imports increased.

The empirical analysis using fixed effects panel data, first and second difference and GMM estimation methods reveals that the effects of the offshoring of services, both intersectorial and intra-sectorial, on employment is not significant and the values obtained are very small in all cases, also when lagged variables are used.

The offshoring of services does not have a statistically significant influence on the employment level of the service industry. Therefore, the idea that the offshoring of services is causing job losses does not appear to hold true in Spain, which corroborates 
with the results of the previous studies conducted in other countries, such as Michel and Rycx (2012) for Belgium and Liu and Trefler (2008) for the United States.

This raises the question of whether the impact of offshoring on improved competitiveness in the service industry may have led to a change in the composition of demand for labour in this sector in Spain over the period considered, without significantly affecting employment in the sector and possibly even leading to rising employment in the medium and long term resulting from efficiency gains in service companies.

\section{References}

Agnese, P., 2012. Employment effects of offshoring across sectors and occupations in Japan. Asian Economic Journal. 26 (4), 289-311.

Aksin, Z.O, Masini, A., 2008. Effective strategies for internal outsourcing and offshoring of business services: an empirical investigation. Journal of Operations Management, 26, 239-256.

Amiti, M., Wei, S.J., 2005. Fear of service outsourcing: is it justified? Economic Policy. 20 (42), 308-347. https://doi.org/10.1111/j.1468-0327.2005.00140.x

Amiti, M., Wei, S.J., 2009. Service Offshoring and Productivity: Evidence from the United States. World Economy. 32 (2), 203-220. https://doi.org/10.1111/j.1467-9701.2008.01149.x

Arellano, M., Bond, S., 1991. Some tests of specification for panel data: Monte Carlo evidence and an application to employment equations. The Review of Economic Studies. 58 (2), 277-297.

Arellano, M., Bover, O., 1995. Another look at the instrumental variable estimation of error-components models. Journal of Econometrics. 68 (1), 29-51.

Bhagwati, J., Panagariya, A., Srinivasan, T.N., 2004. The muddles over outsourcing. Journal of Economic Perspectives. 18 (4), 93-114.

Blinder, A. S., 2006. Offshoring: The next industrial revolution? Foreign Affairs. 85 (82), 113-127.

Bradford, J. J., Klettzer, L.G., 2005. Tradable services: Understanding the scope and impact of services outsourcing. Peterson Institute for International Economics Working Paper 05-9. Washington, DC.

Cadarso, M.A., Gómez, N., López, L. A., Tobarra, M.A., 2008. The EU enlargement and the impact of outsourcing on industrial employment in Spain, 1993-2003. Structural Change and Economic Dynamics. 19, 95-108.

Cadarso, M.A.; Gómez, N.; López, L.A.; Tobarra, M.A., 2012. Offshoring components and their effect on employment: firms deciding about how and where. Applied Economics. 44, 1009-1020.

Campa, J., Goldberg, L.S., 1997. The evolving external orientation of manufacturing industries: Evidence from four countries. Economic Policy Review. 3 (2), 53-81. DOI: $10.3386 / \mathrm{w} 5919$

Contractor, F.J., Kumar, V., Kundu, S.K., Pedersen, T., 2010. Reconceptualizing the firm in a world of outsourcing and offshoring: the organizational and geographical 
relocation of high-value company functions. Journal of Management Studies. 47, 1417-1433.

Crinò, R., 2009. Offshoring, multinationals and labour market: a review of the empirical literature. Journal of Economic Surveys. 23 (2), 197-249.

doi: $10.1111 / \mathrm{j} .1467-6419.2008 .00561 . x$

Crinò, R., 2010. Employment effects of service offshoring: evidence from matched firms. Economic Letters. 107, 253-256.

Eppinger, P. S., 2017. Service offshoring and firm employment, University of Tübingen Working Papers in Economics and Finance, $\mathrm{n}^{\mathbf{0}}$ 103, Eberhard Karls Universität Tübingen, Tübingen. htpp://dex.doi.org/10.15496/publication-19591.

Fariñas, J.C., Martín- Marcos, A., 2010. Foreign sourcing and productivity: evidence at the firm level. World Economy. 33 (3), 482-506. https://doi.org/10.1111/j.1467-9701.2010.01264.x

Feenstra, R.C., Hanson, G.H., 1996. Globalization, outsourcing, and wage inequality. Am. Econ. Rev. 86, 240-245.

Feenstra, R.C., Hanson, G.H., 1999. The impact of outsourcing and high-technology capital on wages: estimates for the United States, 1979-1990. Q. J. Econ. 114, 907940.

Fuster, B., Martínez-Mora, C., 2013. Offshoring of services in Spain: international fragmentation of activities or change in procurement sources? Estudios de Economía Aplicada. 31 (2), 1-22.

Gorg, H., Hanley, A., 2005a. international outsourcing and productivity: evidence from the Irish electronics industry. North American Journal of Economic and Finance. 16 (2), 255-269.

Gorg, H., Hanley, A., 2005b. Labour demand effects of international outsourcing: evidence from plant-level data. International Review of Economics and Finance. 14 (3), 365-376.

Griliches, Z., Hausman, J.A., 1986. Errors in variables in panel data. Journal of Econometrics. 31 (1), 93-118.

Grossman, G. M., Rossi-Hansberg, E., 2008. Trading task: A simple theory of offshoring. American Economic Review. 98, 1978-1997.

Hamermesh, D., 1993. Labour demand. Princenton University Press. Princenton.

Harrison, A., McMillan, M., 2011. Offshoring Jobs? Multinationals and U.S. Employment. The Review of Economics and Statistics. 93 (3), 857-875.

Hausman, J.A. (1978). Specification test in econometrics. Econometrica. 46, 1251-1272.

Hijzen, A., Pisu, M., Upward, R., Wright, P., 2011. Employment, job turnover, and trade in producer services: UK firm-level evidence. Canadian Journal of Economics. 44 (3), 1020-1043.

Horgos, D., 2009. Labor market effects of international outsourcing: how measurement matters. International Review of Economics and Finance. 18, 611-623.

Kirkegaard, J.F., 2007. Offshoring, outsourcing and production relocation: Labor-market effects in the OECD countries and developing Asia. Peterson Institute for International Economics. Working Paper, 07-2. Washington, DC.

Liu, R., Trefler, D., 2008. Much ado about nothing: American jobs and the rise of service outsourcing to China and India. National Bureau of Economic Research. Working Paper 14061.

(DOI): $10.3386 / \mathrm{w} 14061$

Metters, R., 2007. A typology of offshoring and outsourcing in electronically transmitted services. Journal of Operations Management. 26, 198-211. 
Michel, B., Rycx, F., 2012. Does offshoring of materials and business services affect employment? evidence from a small open economy. Applied Economics, 44, 229251.

Moser, C., Urban, D., Di Mauro, B., 2015. On the heterogeneous employment effects of offshoring: identifying productivity and downsizing channels. Economic Inquiry. 53 (1), 220-239.

Myro, R., Labrador, L., 2008. Deslocalización: Concepto, formas y efectos. Principios: Estudios de Economía Política. 10, 97-107.

Olsen, K., 2006. Productivity impacts of offshoring and outsourcing: A review", OECD Science, Technology and Industry Working Papers, 2006/01, OECD Publishing, Paris. https://doi.org/10.1787/685237388034.

Ornaghi, C., Van Beveren, I., Vanormelingen, S., 2017. The impact of service and goods offshoring on employment: firm-level evidence. National Bank of Belgium. Working Paper, 319.

Ottaviano, G., Peri, G., Wrigth, G., 2013. Immigration, offshoring and American jobs. American Economic Review. 103 (5), 1925-1959.

Rishi, M. and Saxena, S.C., 2004. Is outsourcing really as bad as it is made to sound? A re-assessment and some perspective. Available at SSRN: https://ssrn.com/abstract=605802 or http://dx.doi.org/10.2139/ssrn.605802

Sethupathy, G., 2013. Offshoring, wages and employment: Theory and evidence. European Economic Review. 62, 73-97.

Stratman, J. K., 2008. Facilitating offshoring with enterprise technologies: Reducing operational friction in the governance and production of services. Journal of Operations Management. 26, 275-287.

Stringfellow, A., Teagarden, M.B., Nie, W., 2008. Invisible Costs in offshoring services work. Journal of Operations Management. 26, 164-179.

Vivek, S., Banwet, D.K, Shankar, R., 2008. Analysis of interactions among core, transaction and relationship-specific investments: The case of offshoring. Journal of Operations Management. 26, 180-197.

Winkler, D., 2010. Services offshoring and its impact on productivity and employment: evidence from Germany, 1995-2006. World Economy, 33 (12), 1672-1701.

Wrigth, G., 2014. Revisiting the employment impact of offshoring. European Economic Review. 66, 63-83. 